\title{
Doppler Echocardiographic Study in Adolescents and Young Adults with Sickle Cell Anemia
}

\author{
Wolney de Andrade Martins, Evandro Tinoco Mesquita, Delma Maria da Cunha, \\ Luiz A ugusto de Freitas Pinheiro, Luiz José Martins Romêo Fo, Raul Carlos Pareto Jr \\ Niterói - Teresópolis, RJ - Brazil
}

\begin{abstract}
Objective - Anatomical and functional assessment of the heart through Doppler and echocardiography in patients with cell anemia (SCA).
\end{abstract}

Methods - Twenty-five patients with SCA and ages ranging from 14 to 45 years were prospectively studied in a comparison with 25 healthy volunteers. All of them underwent clinical and laboratory evaluation and Doppler echocardiography as well.The measurements were converted into body surface indices.

Results - There were increases in all chamber diameters and left ventricle ( $L V)$ mass of the SCA patients. It was characterised an eccentric hypertrophy of the left ventricle. The preload was increased (left ventricle enddiastolic volume) and the afterload was decreased (diastolic blood pressure, peripheral vascular resistance and endsystolic parietal stress ESPS). The cardiac index was increased due to the stroke volume. The ejection fraction and the percentage of the systolic shortening, as well as the systolic time intervals of the $L V$ were equivalent. The isovolumetric contraction period of the $L V$ was increased. The mitral E-septum distance and the end-systolic volume index (ESVi) were increased. The ESPS/ESVi ratio, a loading independent parameter, was decreased in SCA, suggesting systolic dysfunction. No significant differences in the diastolic function or in the pulmonary pressure occurred.

Conclusion - Chamber dilations, eccentric hypertrophy and systolic dysfunction confirm the evidence of the literature in characterizing a sickle cell anemia cardiomyopathy.

Key words: sickle cell anemia, echocardiography, cardiomyopathy

Universidade Federal Fluminense and Faculdade de Medicina de Teresópolis Mailing address: Wolney de Andrade Martins - Rua Josepha Fernandes Plaza, 3 23845-550 - Dom Bosco - Seropédica - RJ, Brazil
It was certainly not casually but a result of the exuberating cardiovascular manifestations that sickle cell anemia (SCA) was first described by a cardiologist ${ }^{1}$. Due to the influence of African heritage on ethnic formation in Brazil, (SCA) the most prevalent hereditary disease ${ }^{2-4}$. SCA has a high morbidity and mortality $2,5,6$ and its clinical course is more severe than those of the deficiency anemias, constituting a clinical and epidemiological problem.

Sickling of red cells reduces their flexibility resulting, therefore, in retardation of blood flow in microcirculation. The pathogenesis of the disorder is believed to be multifactorial but retardation of the blood flow with its consequent ischemia must be the major factor in the process of continuous and progressive aggression to the myocardium $^{8-10}$.

It is widely agreed that SCA leads to cardiomegaly ${ }^{11-15}$ and to a state of high cardiac output secondary to increase in the preload and decrease in the afterload ${ }^{15-18}$. A hypothesis ${ }^{19}$, later refuted ${ }^{20}$, of a higher prevalence of mitral valve prolapse in patients with SCA was considered. Studies on pulmonary arterial pressure using Doppler echocardiography in these patients are scarce. Systolic and diastolic dysfunctions of the left ventricle are controversial ${ }^{17-21}$. This controversy is partially explained by the interferences of the alterations of the preload and afterload in the echocardiographic parameters of assessment.

Frequently, exuberance of cardiovascular alterations on physical examination and the complaints of dyspnea and fatigue have motivated the referral of the patients with SCA to the cardiologist. Despite the evolution of diagnostic methods in cardiology and the expressive number of individuals with SCA in high complexity care institutions, only a few careful studies on the adult population excluding the heterozygotes and other hemoglobinopathies of the group considered can be found.

Several doubts motivated this study, whose objective is an anatomical and functional assessment of the heart through Doppler echocardiography in adolescents and young adults with SCA. 


\section{Methods}

For 12 months, 50 informed and agreeing volunteers were prospectively studied. They were divided into two groups as follows: the sickle cell group (individuals with sickle cell anemia) and the reference group (healthy volunteers). After excluding the individuals not fulfilling the requirements of the protocol, each group comprised 25 individuals with ages ranging from 14 to 45 years. The mean age for the group with SCAwas 26.56 \pm 9.19 years and, for the reference group, it was $26.76 \pm 7.62$ years. There was statistical equivalence in regard to age $(\mathrm{p}=0.90)$, to $\operatorname{sex}(\mathrm{p}=0.77)$, and to race $(\mathrm{p}=0.92)$. The sickle cell group comprised patients in ambulatory follow-up with clinical and electrophoretic diagnosis of the homozygous form of the $\mathrm{S}$ hemoglobinopathy (HbSS). Patients in painful or in hemolytic crisis or with infection in the previous 4 weeks were excluded from the study, as were those patients transfused in the previous 3 months. Individuals with other diseases were also excluded from the study, as were pregnant women and individuals on drugs with a cardiovascular effect.

The 50 volunteers underwent clinical examination, blood withdrawal for complete hemogram, hemoglobin electrophoresis in cellulose acetate, glycemia, creatinine, urea, sodium and potassium. They also underwent chest teleradiography in the posteroanterior and lateral positions and basal electrocardiography. All patients underwent Doppler echocardiography with the assessment of the blood pressure at a moment close to the obtainment of left ventricle diameters and flows. Blood pressure was taken in the right upper limb, with the patient lying down, through a mercury sphygmomanometer, exclusively used for this study. The left ventricle end-systolic pressure(ESP) was inferred through an equation of regression obtained in cardiac catheterization and validated in the literature ${ }^{17,22-24}$, where the left ventricle end-systolic pressure was equal to the systolic pressure in sphygmomanometry multiplied by 0.66 and added to 13.55 , a constant.

Doppler echocardiography was always performed by the same person with the same device, with a transducer of $3.5 \mathrm{MHz}$, concomitantly with basal electrocardiography. Arithmetical means of at least 3 consecutive cardiac cycles of all echocardiographic variables were used. The examinations were recorded and revised by 2 independent echocardiographers who ignored the precedent results and proceeded to the qualitative analysis of the examinations. Echocardiographic variables were corrected to the body surface of each patient and referred to as indices ${ }^{25}$.

It is important to emphasize that some assessments were performed according to the following special criteria: 1 ) the left ventricular mass was estimated through the equation of Bennett and Evans ${ }^{26}$, considering the determinations of the Penn's convention ${ }^{27}$ for measurement acquisition. The equation of Bennett and Evans ${ }^{26}$ determines that left ventricular mass $=\left[(2 \times \mathrm{DTPW}+\mathrm{DD})^{3}-\mathrm{DD}^{3}\right] \times 1.05$, where DTPW $=$ diastolic thickness of the posterior wall of the left ventricle and $\mathrm{DD}=$ diastolic diameter of the left ventricle; 2 ) the relative thickness of the septum (RTS) was calculated through a formula in which RTS is twice the diastolic thi- ckness of the interventricular septum divided by the diastolic diameter of the left ventricle. A value $<0.45$ was considered normal ${ }^{28} ; 3$ ) the stroke volume (SV) was calculated through the integral of the flow in the left ventricle outflow tract and the aortic area estimated through M-mode echocardiography ${ }^{28-31}$; 4) the total peripheral vascular resistance (TPVR) was estimated through the division of the mean blood pressure (MBP) by the cardiac output (CO) multiplied by the constant $\left.80^{25} ; 5\right)$ the systolic time intervals of the left ventricle were obtained through assessment of the intermediate flowchart between the transmitral and the left ventricle outflow tract compared with concomitant basal electrocardiography ${ }^{32}$. The criteria for diagnosing mitral valve prolapse were the following: systolic bulging of one or two leaflets into the left atrium in the longitudinal parasternal cross-section; the posterior meso- or end-systolic movement of the mitral valve or the excessive amplitude of the anterior leaflet in diastole (CE distance $>25 \mathrm{~mm})^{32}$;7) the left ventricle end-systolic thickening of the posterior wall (ESTPW) was calculated through a modification of the method proposed by Hugenholtz et al ${ }^{33}$, in which ESTPW $=0.5\left[(\mathrm{DD}+2 \mathrm{DTPW})^{3}-(\mathrm{DD})^{3}+(\mathrm{SD})^{3}\right]^{1 / 3}-$ $0.5 \times \mathrm{SD} ; 8)$ the end-systolic parietal stress (ESPS) was obtained through the following equation ${ }^{17,22,34-36}$ :

$$
\mathrm{ESPS}=\frac{\mathrm{ESP} \quad \mathrm{X} \mathrm{SD}}{4 \mathrm{XESTPW}\left(1+\frac{\mathrm{ESTPW}}{\mathrm{SD}}\right)}
$$

9) the parietal stress/end-systolic volume index ratio was obtained by dividing the end-systolic parietal stress by the end-systolic volume index (ESVi) of the left ventricle ${ }^{17} ; 10$ ) the pulmonary arterial pressure (PAP) was inferred from the flowchart of the right ventricle outflow tract through the equations proposed by Isobe et al ${ }^{37}$.

The statistical analysis was performed through the Student $t$ test or the Mann-Whitney's test for independent samples or through the chi-square test or the Fisher exact test for proportions. Pearson product moment correlation was used to measure the degree of association between two interval variables. The criterion for significance determination was $5 \%$.

\section{Results}

The uni- and bidimensional studies and also the Doppler results did not show valvar lesions, structural defects or pericardial alterations in the 50 individuals, except one case of mitral valve prolapse with mild regurgitation, without myxomatous degeneration, in one patient with SCA.

All cavitary diameters were significantly increased, as were the muscle thickness and the estimated muscle mass of the left ventricle in the group of the patients with SCA. The left ventricle mass index was increased with preservation of the relative thickness of the septum within normal values, characterizing a pattern of eccentric hypertrophy in the patients with SCA (table I).

Patients with SCA had load alterations in the parameters of indirect evaluation. The end-diastolic volume index of the left ventricle (EDVi) (preload) was increased, contrasting with the expressive reduction in the diastolic blood pressure (DBP), in the total peripheral vascular 


\begin{tabular}{|c|c|c|c|}
\hline \multicolumn{4}{|c|}{$\begin{array}{l}\text { Table I - Comparison between cavitary diameters, muscle } \\
\text { thickness and mass in the sickle cell anemia and reference groups }\end{array}$} \\
\hline Variable & Sickle & Reference & $\mathrm{p}$ \\
\hline Aoi $\left(\mathrm{cm} / \mathrm{m}^{2}\right)$ & $1.81 \pm 0.21$ & $1.45 \pm 0.19$ & $<0.001$ \\
\hline $\operatorname{LAi}\left(\mathrm{cm} / \mathrm{m}^{2}\right)$ & $2.81 \pm 0.33$ & $1.94 \pm 0.24$ & $<0.001$ \\
\hline $\operatorname{RVDD}\left(\mathrm{cm} / \mathrm{m}^{2}\right)$ & $1.39 \pm 0.34$ & $1.15 \pm 0.27$ & $<0.009$ \\
\hline $\operatorname{LVDD}\left(\mathrm{cm} / \mathrm{m}^{2}\right)$ & $3.47 \pm 0.40$ & $2.81 \pm 0.21$ & $<0.001$ \\
\hline $\operatorname{LVSD}\left(\mathrm{cm} / \mathrm{m}^{2}\right)$ & $2.19 \pm 0.32$ & $1.79 \pm 0.20$ & $<0.001$ \\
\hline $\operatorname{IVSDi}\left(\mathrm{cm} / \mathrm{m}^{2}\right)$ & $0.66 \pm 0.15$ & $0.46 \pm 0.08$ & $<0.001$ \\
\hline $\operatorname{IVSSi}\left(\mathrm{cm} / \mathrm{m}^{2}\right)$ & $0.88 \pm 0.19$ & $0.62 \pm 0.10$ & $<0.001$ \\
\hline LVDTPW $\left(\mathrm{cm} / \mathrm{m}^{2}\right)$ & $0.66 \pm 0.15$ & $0.41 \pm 0.06$ & $<0.001$ \\
\hline LVSTPW $\left(\mathrm{cm} / \mathrm{m}^{2}\right)$ & $1.06 \pm 0.17$ & $0.80 \pm 0.20$ & $<0.001$ \\
\hline Male Mi $\left(\mathrm{g} / \mathrm{m}^{2}\right)$ & $178.80 \pm 66.61$ & $91.25 \pm 15.71$ & $<0.001$ \\
\hline Female Mi $\left(\mathrm{g} / \mathrm{m}^{2}\right)$ & $147.97 \pm 53.71$ & $72.94 \pm 8.60$ & $<0.001$ \\
\hline RTS & $0.38 \pm 0.09$ & $0.33 \pm 0.06$ & 0.013 \\
\hline \multicolumn{4}{|c|}{$\begin{array}{l}\text { AoI- aortic index; LAi-left atrium index; RVDDi- right ventricle diastolic } \\
\text { diameter; LVDDi-left ventricle diastolic diameter; LVSDi-left ventricle } \\
\text { systolic diameter; IVSDi- interventricular septum diastolic index; IVSSi- } \\
\text { interventricular septum systolic index; LVDTPWi- left ventricle } \\
\text { diastolic thickness of the posterior wall; LVSTPWi- left ventricle } \\
\text { systolic thickness of the posterior wall; Mi- mass index; RTS- relative } \\
\text { thickness of the septum. }\end{array}$} \\
\hline
\end{tabular}

resistance estimated (TPVR), and in the end-systolic parietal stress (afterload) (table II).

Heart rate was equivalent in both groups: group of patients with SCA $(69.96 \pm 9.17 \mathrm{bpm})$ and reference group $(66.88 \pm 9.48 \mathrm{bpm})(\mathrm{p}=0.240)$.

Systolic time intervals of the left ventricle, such as electromechanical systole (EMS), preejection period (LVPEP), and ejection time (LVET) were statistically similar in both groups. Only the isovolumetric contraction period (IVCP) was increased in the patients with SCA (table III).

The indices of the ejection phase, such as ejection fraction (EF) and the percentage of systolic shortening $(\% \mathrm{SS})$, were equivalent. The stroke volume (SV) and the

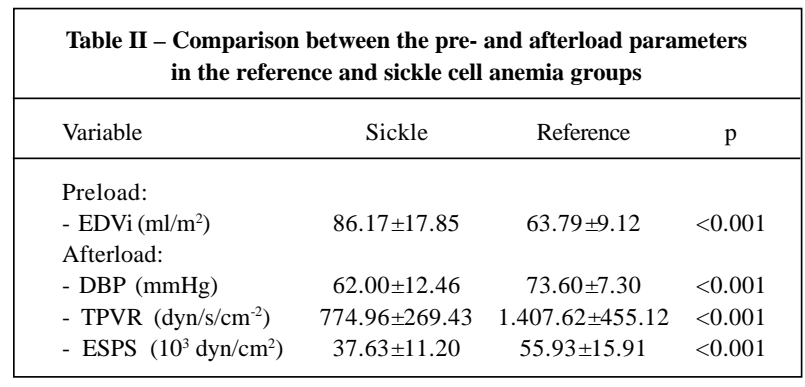

\begin{tabular}{|c|c|c|c|}
\hline \multicolumn{4}{|c|}{$\begin{array}{l}\text { Table III - Comparison between the left ventricle systolic time } \\
\text { intervals in the reference and sickle cell anemia groups }\end{array}$} \\
\hline Variable & Sickle & Reference & $\mathrm{p}$ \\
\hline EMS (s) & $0.399 \pm 0.030$ & $0.390 \pm 0.025$ & 0.290 (ns) \\
\hline PEP (s) & $0.102 \pm 0.017$ & $0.100 \pm 0.020$ & $0.610(\mathrm{~ns})$ \\
\hline ET $\quad(s)$ & $0.296 \pm 0.027$ & $0.287 \pm 0.033$ & $0.290(\mathrm{~ns})$ \\
\hline $\operatorname{IVCP}(\mathrm{s})$ & $0.094 \pm 0.058$ & $0.048 \pm 0.020$ & $<0.001$ \\
\hline
\end{tabular}

cardiac index (CI) were significantly increased in the group of patients with SCA (table IV).

The parameters of indirect assessment of the systolic function studied indicate the presence of dysfunction in the group of patients with SCA. The "the distance" between the mitral E point and the interventricular septum (mitral Eseptum distance) was $7.29 \pm 3.44 \mathrm{~mm}$ in the group of patients with SCA and $5.37 \pm 3.22 \mathrm{~mm}$ in the reference group $(\mathrm{p}=0.048)$. The end-systolic volume index of the left ventricle (ESVi) was increased $\left(29.55 \pm 10.48 \mathrm{ml} / \mathrm{m}^{2}\right)$ in the group of patients with sicle cell anemia as compared with the reference group $\left(22.07 \pm 5.68 \mathrm{ml} / \mathrm{m}^{2}\right)(\mathrm{p}=0.003)$.

The ratio between the end-systolic parietal stress and the end-systolic volume index , considered a parameter independent from load alterations and, therefore, more reliable in representing the myocardial intrinsic contractile function, indicated systolic dysfunction in the patients with SCA. In the patients with SCA, this ratio $(1.30 \pm 0.35)$ was approximately half the value of the ratio in the reference group $(2.57 \pm 0.47)(\mathrm{p}<0.001)$.

Four parameters of diastolic function were studied: time of isovolumetric relaxation (TIVR), speed of the mitral EF slope (MEF), relation between the mitral $E$ and A flowcharts (E/A), and the deceleration of the mitral A wave (\A). Out of these 4 parameters, 3 had a tendency to be different in the groups, without showing, however, statistical significance at the $5 \%$ level (table V).

The mean values of the systolic pulmonary arterial pressure (SPAP), the mean pulmonary arterial (MPAP), and the diastolic pulmonary arterial pressure (DPAP), inferred fraw the relation between right ventricle preejection period (RVPEP) and the acceleration time of the pulmonary flow (ATPF) did not differ between the two groups (table VI).

\begin{tabular}{|c|c|c|c|}
\hline \multicolumn{4}{|c|}{$\begin{array}{l}\text { Table IV - Comparison between the indices of the ejection phase in } \\
\text { the reference and sickle cell anemia groups }\end{array}$} \\
\hline Variable & Sickle & Reference & $\mathrm{p}$ \\
\hline $\mathrm{EF}(\%)$ & $66.07 \pm 8.14$ & $64.77 \pm 6.69$ & 0.540 (ns) \\
\hline$\% \mathrm{SS}(\%)$ & $36.81 \pm 6.41$ & $36.25 \pm 5.42$ & 0.730 (ns) \\
\hline SV (l) & $0.125 \pm 0.036$ & $0.081 \pm 0.020$ & $<0.001$ \\
\hline CI $\left(1 / \mathrm{min} / \mathrm{m}^{2}\right)$ & $5.90 \pm 1.77$ & $3.14 \pm 0.91$ & $<0.001$ \\
\hline
\end{tabular}

\begin{tabular}{|lccc|}
\hline \multicolumn{4}{|c|}{$\begin{array}{c}\text { Table V - Comparison of the diastolic function parameters } \\
\text { between the reference and sickle cell anemia groups }\end{array}$} \\
\hline Variable & Sickle & Reference & $\mathrm{p}$ \\
\hline TIVR $(\mathrm{s})$ & $0.087 \pm 0.025$ & $0.075 \pm 0.018$ & 0.063 \\
$\mathrm{MEF}(\mathrm{mm} / \mathrm{s})$ & $114.23 \pm 21.67$ & $131.19 \pm 38.58$ & 0.062 \\
$\mathrm{E} / \mathrm{A}$ & $1.902 \pm 0.453$ & $2.266 \pm 0.780$ & 0.052 \\
$\mathrm{~A}\left(\mathrm{~m} / \mathrm{s}^{2}\right)$ & $5.158 \pm 2.094$ & $4.397 \pm 1.276$ & 0.120 \\
\hline
\end{tabular}

\begin{tabular}{|lrrr|}
\hline \multicolumn{4}{|c|}{$\begin{array}{c}\text { Table VI - Comparison of pulmonary arterial pressure between } \\
\text { the reference and sickle cell anemia groups }\end{array}$} \\
\hline Variable & Sickle & Reference & $\mathrm{p}$ \\
\hline SPAP (mmHg) & $18.38 \pm 9.88$ & $17.72 \pm 6.04$ & 0.810 \\
MPAP (mmHg) & $11.16 \pm 6.49$ & $10.73 \pm 3.97$ & 0.810 \\
DPAP (mmHg) & $6.73 \pm 4.79$ & $6.41 \pm 2.93$ & 0.810 \\
\hline
\end{tabular}




\section{Discussion}

When comparing these results with those in the literature, one must pay attention to methodological errors often found. One of the most frequent errors is related to the heterogeneity of the groups studied. Patients are grouped without electrophoretic confirmation or with different sickle cell diseases, pediatric and adult populations are mixed, as are ambulatory patients and the decompensated ones, and patients being transfused and patients with recent hemolytic crises.

If, on the one hand, it is agreed in the literature that SCA leads to a chamber enlargement of the left atrium and ventricle $^{14,15,18,20,21,38-42}$, on the other hand, the enlargement of the right ventricle, when analyzed in absolute values, is considered controversial. Estrade et al ${ }^{15}$ emphasize that the enlargement of the right ventricle occurs later than that of the left ventricle. Analysis of each case compared with the normal values of the literature shows that there is an increase in the right ventricle index in $28 \%$ of the patients with SCA contrasted to the increase in the left ventricle index in $80 \%$ of these same patients with SCA in our series. Some authors do not find an enlargement of the right ventricle in patients with sickle cell anemia probably because they work with absolute values. Patients with SCA are known to have a smaller body surface, influencing the chamber diameters of the heart ${ }^{18,21,41}$. The smaller frequency of right ventricle enlargement as compared with that of the left ventricle opposes the hypothesis that the alterations found in SCA are exclusively secondary to the volumetric overload common to chronic anemias. If the right ventricle enlargement were real, it would be proportional, or even more frequent, than enlargement of the left ventricle. Some factors might affect more specifically the left side of the heart, such as chronic ischemia acting upon the hypertrophied ventricular wall.

The literature shows an increase in the muscle mass of the left ventricle in patients with SCA, almost twice that which would be expected, either on Doppler echocardiography and on autopsy ${ }^{7,18,21,40,41}$. Both hypertrophy and dilation are known to progress with age ${ }^{20,21}$, being found even in the pediatric population ${ }^{14,15}$. Hypertrophy may be a result of the compensatory mechanism to the volumetric overload, in an attempt to reduce parietal stress ${ }^{34}$.

The hypothesis of a higher prevalence of mitral valve prolapse in SCA was formulated by Lippman et al ${ }^{19}$ studying 57 patients with SCA and finding $25 \%$ with mitral valve prolapse. A possible mechanism would be ischemia of the papillary muscles during episodes of aggravation of the disease, because of their terminal localization in coronary circulation ${ }^{43}$. The cooperative study of sickle cell disease ${ }^{20,44}$ reports a case of mitral valve prolapse in 225 patients studied. Our study, like others using bidimensional echocardiography ${ }^{17,40,44}$, had statistically insufficient series for conclusions in regard to prevalence of mitral valve prolapse in patients with SCA.

Preload is increased due to increase in the plasmatic volume $^{16-18}$, while reduction in the afterload is due to intense peripheral vasodilation secondary to release of bradykinin and adenosine ${ }^{45,46}$. These load alterations assessed in the study through the end-diastolic volume index (EDVi), the diastolic slool pressure (DBP), the total peripheral vascular resistence(TPVR), and the end systolic parietal stress (ESPS) lead to the status of high cardiac output of the SCA. It is worth emphasizing that the high cardiac index is exclusively secondary to the increase in stroke volume, since the heart rate is normal in patients with $\mathrm{SCA}^{16,39,47-50}$.

The normal values for systolic time intervals eletromecanical systole (EMS), tempo de ejeção (ET), and preejection perial (PEP) in patients with SCA in this study are in accordance with those in the literature ${ }^{14,21,51}$. Abdullah et al ${ }^{52}$ emphasize that the systolic time intervals are influenced by load alterations found in chronic anemias, and a pseudonormalization of them may occur. the isovolumetria contraction perial (IVCP) is known to be increased in heart failure ${ }^{32}$. In our series, isovolumetria contraction perial (IVCP) is increased. Comparisons, however, were not possible due to the nonexistence of data in similar populations.

Denenberg et al ${ }^{17}$ were the first to stress that dissonance between clinical and laboratory evidence of heart failure in SCA and echocardiography was due to a pseudonormalization of the indices of the ejection phase (EF and $\%$ SS) by load alterations. These indices were the only ones used to assess the systolic function in patients with SCA. Use of the end-systolic parietal stress/the end-systolic volume index (ESVi) ratio, considered independent from load alterations, was proposed. With a small series, results indicating the expected systolic dysfunction were obtained. In this study, we repeated that methodology with a larger and better-controlled series and we obtained similar results, but with a higher level of statistical significance. In addition to the increased end-systolic parietal stress/the end-systolic volume index (ESVi) ratio, increase in the mitral E-septum distance, in the the isovolumetria contraction perial (IVCP), and in the the end-systolic volume index (ESVi) confirmed the existence of systolic dysfunction in patients with SCA.

In the present study, a tendency suggesting a pattern of deficiency of relaxation in 3 out of the 4 parameters studied was found. This alteration could be attributed to myocardial hypoxia leading to kinetic alterations of calcium in the relaxation phase. Few studies analyzed the diastolic function in patients with SCA. One of these studies, grouped different hemoglobinopathies ${ }^{53}$ and another study considered only one parameter ${ }^{18}$. However, the greatest limitation is technical. It is known that increased preload influences the parameters that assess the diastolic function on Doppler, leading to a pseudonormalization ${ }^{54,55}$. It is difficult, however, to know precisely what the effects of the combination of increased preload with decreased afterload would be upon the Doppler echocardiographic parameters. Study of the pulmonary vein flow and of the time of deceleration of the mitral flow, which was not performed in this study, might add some information. A further study is required to carefully evaluate the diastolic function in patients with SCA.

Estimation of the pulmonar artery pressure (PAP) on Doppler echocardiography through the tricuspid regurgita- 
ting flow calculated with the Bernoulli's equation was considered the most accurate by Feigenbaum ${ }^{56}$, and is certainly the most known. However, it has the limitation of not being able to be used in serial studies of comparison with normal individuals, in whom the maximum speed of tricuspid regurgitation cannot usually be obtained. The scarce studies assessing the pulmonar artery pressure (PAP) on Doppler echocardiography in sickle cell anemia used an inaccurate methodology, such as the grouping of different hemoglobinopathies, or were retrospective ${ }^{57}$. Isobe et al ${ }^{37}$ concluded that the right ventricle preejection period (RVPEP)/ time of the pulmonary flow (ATPF) ratio was the best predictor of the the pulmonar artery pressure (PAP). However, no reference in regard to the probable influence of load alterations upon these parameters was found. In this study, many parameters proposed in the literature were calculated, such as the relationships between ATPF and the right ventricle ejection time; on average, all of them were normal. The load alterations that have influenced the left ventricle may have also influenced the right ventricle, interfering with and underestimating the pulmonary arterial pressure inferred on Doppler echocardiography.

Chamber dilations, the eccentric pattern of left ventricular hypertrophy, alterations in the pre- and afterload with their consequences, and the systolic dysfunction assessed by the mitral E-septum distance, by the isovolumetric contraction period (IVPC), by the end systolic volume index (ESVi) and by the end-systolic parietal stress/the end systolic volume index (ESVi) ratio observed on Doppler echocardiography confirm the clinical and histopathologic evidence of the literature, characterizing a sickle cell anemia cardiomyopathy.

\section{References}

1. Herrick JB. Peculiar elongated and sickle-shaped red blood corpuscles in a case of severe anemia. Arch Intern Med 1910; 6:517-21.

2. Silva RBP, Ramalho AS, Cassorla RMS. A anemia falciforme como problema de saúde pública no Brasil. Rev Saúde Pública 1993; 27: 54-8.

3. Zago MA, Costa FF. Hereditary hemoglobin disorders in Brazil. Trans R Soc Trop Med Hyg 1995; 79: 385-8.

4. Naoum PC. Distribuição geográfica das hemoglobinopatias. In: Naoum PC Hemoglobinopatias e Talassemias. São Paulo: Sarvier, 1997: 137-43.

5. Hutz MH. História natural da anemia falciforme em pacientes da região metropolitana do Rio de Janeiro (Tese Doutorado em Ciências). Porto alegre, UFRGS, 1981: 275 p.

6. Platt OS, Brambilla DJ, Rosse WF, et al. Mortality in sickle cell disease: life expectancy and risk factors for early death. New Engl J Med 1994; 330: 1639-64.

7. Bertrand E. Drépanocytose et coeur. Arch Mal Coeur 1989; 82:1881-4.

8. Klug PP, Lessin LS, Radice P. Rheological aspects of sickle cell disease. Arch Intern Med 1974; 133: 577-90.

9. Horne MK. Sickle cell anemia as a rheologic disease. Am J Med 1981; 70: 288-98.

10. Martins WA, Mesquita ET, Cunha DM, et al. Alterações cardiovasculares na anemia falciforme. Arq Bras Cardiol 1997; 70: 365-70.

11. Uzsoy NK. Cardiovascular findings in patients with sickle cell anemia. Am J Cardiol 1964; 13: 320-8.

12. Karayalcin G, Rosner F, Kim KY, Chandra P, Aballi AJ. Sickle cell anemia: clinical manifestations in 100 patients and review of the literature. Am J Med Sci 1975; 269: 51-68

13. Louis-Gustave A, Louis-Gustave R. Signes cardiovasculaires de la drépanocytose. Arch Mal Coeur 1977; 70: 135-40.

14. Herdy GVH, Pinheiro LAF, Couto AA, Gabetto M. Miocardiopatia e anemia falciforme em crianças. Arq Bras Cardiol 1987; 49: 87-93.

15. Estrade G, Poitrineau O, Bernasconi F, Garnier D, Donatien Y. Fonction ventriculaire gauche et drépanocytose. Arch Mal Coeur 1989; 82: 1975-81.

16. Lindsay JJ, Meshel JC, Patterson H. The cardiovascular manifestations of sickle cell anemia. Arch Intern Med 1974; 133: 643-51.

17. Denenberg BS, Criner G, Jones R, Spann JF. Cardiac function in sickle cell anemia. Am J Cardiol 1983; 51: 1674-8

18. Balfour IC, Covitz W, Davis H, Rao PS, Strong WB, Alpert BS. Cardiac size and function in children with sickle cell anemia. Am Heart J 1984; 108: 345-50.

19. Lippman SM, Ginzton LE, Thigpen T, Tanaka KR, Laks MM. Mitral valve prolapse in sickle cell disease. Arch Intern Med 1985; 145: 435-8

20. Covitz W, Esperland M, GallagherD, Hellenbrand W,Leff S, Talner N. The heart in sickle cell anemia: the cooperative study of sickle cell disease. Chest 1995; 108: 1214-9

21. Gerry JL, Baird, MG, Fortuin NJ. Evaluation of left ventricular function in patients with sickle cell anemia. Am J Med 1976; 60: 968-72.

22. Marsh JD, Green LH, Wynne J, Cohn PF, Grossman W. Left ventricular endsystolic pressure-dimension and stress-lenght relations in normal human subjects. Am J Cardiol 1979; 44: 1311-7.

23. Mehmel HC, Stockins B, Ruffmann K, Olshausen K, Schuler G, Kübler W. The li- nearity of the end-systolic pressure-volume relationship in man and its sensitivity for assessment of the left ventricular function. Circulation 1981; 63: 1216-22.

24. Borow KM, Laurence HG, Grossman W, Braunwald E. Left ventricular end-systolic stress-shortening and stress-length relations in humans: normal values and sensitivity to inotropic state. Am J Cardiol 1982; 50: 1301-8.

25. Pinheiro LAF. Alguns aspectos da farmacocinética e da farmacodinâmica da digoxina-Emprego na pesquisa clínica (Tese concurso professor titular do Departamento de Medicina Clínica). Niterói, UFF, 1993: 157 p.

26. Bennett DH, Evans DW. Correlation of left ventricular mass determined by echocardiography with vetorcardiographic and eletrocardiographic voltage measurements. Br Heart J 1974; 36: 981

27. Devereux RB, Alonso DR, Lutas EM, et al. Echocardiographic assessment of left ventricular hypertrophy: comparison to necropsy findings. Am J Cardiol 1986; 57: 450-8.

28. Simone G, Lorenzo L, Moccia D, Constantino G, Buonissimo S, Divitiis O. Hemodynamic hypertrophied left ventricular patterns in systemic hypertension. Am J Cardiol 1987; 60: 1317-21.

29. Loeppky JA, Hoekenga DE, Greene R, Luft UC. Comparisson of noninvasive pulsed Doppler and Fick measurements of stroke volume in cardiac patients. Am Heart J 1984; 107: 339-46.

30. Rein AJ, Hsieh, KS, Elixson M, et al. Cardiac output estimated in the in pediatric intensive care unit using a continuous-wave Doppler computer: validation and limitations of the technique. Am Heart J 1986; 112: 97-103.

31. Bouchard A, Blumlein S, Schiller NB, et al. Measurement of left ventricular stroke volume using continuous wave Doppler echocardiography of the ascending aorta and M-mode echocardiography of the aortic valve. J Am Coll Cardiol 1987; 9: 75-83.

32. Morcerf FAP. Ecocardiografia uni-bidimensional e Doppler. Rio de Janeiro: Revinter, 1990: 151 e 217.

33. Hugenholtz PA, Kaplan E, Hall E. Determination of left ventricular wall thickness by angiography. Am Heart J 1969; 78: 513-22.

34. Grossman W, Braunwald E, Mann T, McLaurin LP, Green LH. Contractile state of the left ventricle in man as evaluated from end-systolic pressure-volume relations. Circulation 1977; 56: 845-52.

35. Sagawa K. The end-systolic pressure-volume relation of the ventricle: definition, modifications and clinical use. Circulation 1981; 63: 1223-7.

36. Reicheck N, Wilson J, Sutton MSJ, Plappert TA, Goldberg S, Hirshfeld JW. Noninvasive determination of left ventricle end-systolic stress: validation of the method and initial application. Circulation 1982; 65: 99-108.

37. Isobe M, Yazaki $\mathrm{Y}$, Takaku F, et al. Prediction of pulmonary arterial pressure in adults by pulsed Doppler echocardiography. Am J Cardiol 1986; 57: 316-21.

38. Herdy GVH. Alterações cardíacas na eritrofalcemia (Tese para Professor Titular do DepartamentoMaterno-Infantil), Niterói:UniversidadeFederal Fluminense, 1985:99p.

39. Gaffney JW, Bierman FZ, Donnelly CM, Sutton M, Piomelli S, Gersony WM. Cardiac adaptations to tranfusion/chelation therapy of homozygote sickle cell anemia. Am J Cardiol 1988; 62: 121-30.

40. Simmons BE, Santhanam V, Castaner A, Rao KRP, Sachdev N, CooperR. Sickle cell 
disease: two-dimensional echo and Doppler ultrassonographic findings in hearts of adult patients with sickle cell anemia. Arch Intern Med 1988; 148: 1526-8.

41. Lester LA, Sodt PC, Hutcheon N, Arcilla RA. Cardiac abnormalities in children with sickle cell anemia. Chest 1990; 98: 1169-74.

42. Blandón R, Leandro IM, Altafulla M, Fernández RD. Evaluation ecocardiografica de pacientes con anemia falciforme. Rev Med Panamá 1991; 16: 88-97.

43. Berezowski K, Mautner GC, Roberts WC. Scarring of the left ventricular pappilary muscles in sickle-cell disease. Am J Cardiol 1992; 70: 1368-74.

44. Brown J, Covitz W, Geer M. Mitral valve prolapse in sickle cell anemia. Arch Intern Med 1986; 146: 208

45. FowlerNO, Holmes JC. Ventricular function in anemia. J Appl Physiol 1971;31:260-5.

46. Shulman LN, Braunwald E, Rosenthal DS. Hematological-oncological disorders and heart disease. In: Braunwald E. Heart disease: a textbook of cardiovascular medicine. 5 ed. Philadelphia: WB Saunders, 1997: 1786-808.

47. Leight L, Snider TH, Clifford GO, Hellems H. Hemodynamic studies in sickle cell anemia. Circulation 1954; 10: 653-62.

48. Duke M, Abelmann WH. The hemodynamic response to chronic anemia. Circulation 1969; 34: 503-15.

49. Cropp GJA. Cardiovascular function in children with severe anemia. Circulation 1969; 34: 775-84
50. Varat MA, Adolph RJ, Fowler NO. Cardiovascular effects of anemia. Am Heart J 1972; 83: 415-26.

51. Matsubara LS, Trezza E, Machado PEA. Estudo fonomecanocardiográfico de portadores de hemoglobinopatia S. Arq Bras Cardiol 1981; 36: 185-7.

52. Abdullah AK, Siddiqui MA, Tajuddin M. Systolic time intervals in chronic anemia. Am Heart J 1977; 94: 287-91.

53. Lewis JF, Maron BJ, Castro O, Moosa YA. Left ventricular diastolic filling abnormalities identified by Doppler echocardiography in assymptomatic patients with sickle cell anemia. J Am Coll Cardiol 1991; 17: 1473-8.

54. Choong CY, Herrmann HC, Weyman AE. Preload dependence of Doppler- derived indexes of left ventricular diastolic function in humans. J Am Coll Cardiol 1987; 10: 800-8.

55. Stoddard MF, Pearson AC, Kern MJ, Ratcliff J, Mrosek DG, Labovitz AJ. Influence of alteration in preload on the pattern of left ventricular diastolic filling as assessed by Doppler echocardiography in humans. Circulation 1989; 79: 1226-36.

56. Feigenbaum H. Echocardiography. $5^{\text {th }}$ ed. Philadelphia: Lea \& Febiger, 1993: $695 \mathrm{p}$

57. Sutton LL, Castro O, Cross DJ, Spencer JE, Lewis JF. Pulmonary hypertension in sickle cell disease. Am J Cardiol 1994; 74: 626-8. 